\title{
TEATRO POLONÊS EM TRADUÇÃO NO BRASIL: CORTINA! (ALGUNS APONTAMENTOS) $^{1}$
}

\author{
Polish Theatre on Stage in Brazil: Some Remarks on Brazilian Translations \\ of Polish Drama and Texts for the Stage
}

Marcelo PAIVA DE SOUZA

Universidade Federal do Paraná mrclpvdsz@hotmail.com

https://orcid.org/0000-0002-3632-1143

\begin{abstract}
RESUMO: Duas metas estão em vista no presente artigo. Primeiro, rastrear a presença do teatro polonês, de 2009 para cá, nos palcos brasileiros, registrando - e comentando brevemente - tanto apresentações de artistas da cena da Polônia no Brasil, quanto montagens brasileiras de textos da dramaturgia polonesa. Esse retrospecto de modo algum se pretende um panorama exaustivo da presença da Polônia nos últimos dez anos de nossa vida teatral. Permitirá, no entanto, que sejam trazidas à baila questões importantes a respeito do teatro polonês em tradução entre nós. Propõe-se um esboço de reflexão e de debate acerca do assunto, na interface da polonística, dos estudos teatrais e dos estudos da tradução. PALAVRAS-CHAVE: Teatro polonês no Brasil; Traduzir (para) teatro; Polonística.
\end{abstract}

\begin{abstract}
The present article has two goals. Firstly, to trace the presence of Polish theatre, from 2009 until today, on Brazilian stages, recording - and briefly commenting on - both performances by Polish artists in Brazil, and Brazilian productions of Polish dramatic texts. This retrospect is not intended to be an exhaustive panorama of Polish presence in Brazilian theatre life over the last ten years. But it allows us to bring out important issues concerning the Brazilian translations of Polish drama and texts for the stage. I draw a few reflections on this subject at the intersection of Polish Studies, Theatre Studies and Translation Studies. KEYWORDS: Polish theatre in Brazil; drama/theatre translation; Polish Studies.
\end{abstract}

STRESZCZENIE: Niniejszy artykuł ma dwa główne cele. Po pierwsze, staram się prześledzić obecność polskiego teatru od 2009 roku do dziś

\footnotetext{
${ }^{1}$ Este artigo é resultado das atividades que desenvolvi ao longo de 2019, em um pós-doutorado no Programa de Pós-Graduação em Estudos da Tradução (POET) da Universidade Federal do Ceará, sob a supervisão do Prof. Dr. Walter Carlos Costa.
} 
na brazylijskich scenach, wspominając - i krótko komentując - zarówno przedstawienia polskich artystów w Brazylii, jak i brazylijskie spektakle oparte na polskich tekstach dramatycznych. Ten krótki przegląd nie jest w zamierzeniu wyczerpującą panoramą polskiej obecności w życiu teatralnym Brazylii w ciągu ostatnich dziesięciu lat. Pozwala jednak wydobyć na jaw istotne kwestie dotyczące przekładów polskiego dramatu i polskich tekstów scenicznych u nas. Podejmuję kilka refleksji na ten temat na styku polonistyki, teatrologii i przekładoznawstwa. SŁOWA KLUCZOWE: Polski teatr w Brazylii; przekład dramatu/ przekład dla teatru; Polonistyka.

Duas metas estão em vista no que segue. Primeiro, rastrear a presença do teatro polonês, de 2009 para cá, nos palcos brasileiros, registrando e comentando algumas empreitadas especialmente significativas - aí incluídas, a título de exemplificação, tanto apresentações de artistas da cena da Polônia no Brasil, quanto montagens brasileiras de textos da dramaturgia polonesa. Esse breve retrospecto, advirta-se, não alimenta qualquer pretensão de exaustividade, nem no que toca à sua abrangência documental, nem muito menos em termos de prospecção analítica ou de juízo crítico dos casos de interesse. Todavia, sem embargo de seu modesto alcance, o incipiente levantamento aqui apresentado ${ }^{2}$ deve fornecer o pano de fundo necessário para uma segunda manobra, um esboço de reflexão teórica e de debate, voltados para a vasta problemática da tradução em suas múltiplas, complexas interfaces com o universo teatral. Consideradas as especificidades do traduzir (para o) teatro, como processo de (re)criação de linguagem e de in(ter)venção intercultural, submeto a questão a escrutínio pelo prisma disciplinar da polonística em sua atual configuração institucional em nosso país: que tarefas, que desafios assim se descortinam? Que possibilidades se delineiam no horizonte em um espaço de convergência - e de virtual intercâmbio e cooperação - dos trabalhos do tradutor e do criador cênico, do estudioso da tradução, do pesquisador teatral e do polonista?

\section{TEATRO POLONÊS EM CENA NO BRASIL NA ÚLTIMA DÉCADA}

Antes de prosseguir, os limites do levantamento realizado requerem uma explicação, bem como uma ressalva. O marco temporal estabelecido justifica-se por uma razão simples: corresponde ao aniversário que comemoramos neste Encontro, ${ }^{3}$ os dez

\footnotetext{
${ }^{2}$ Mais pesquisas e estudos, quiçá, haverão de tirar proveito dos dados aqui reunidos!

${ }^{3}$ O I Encontro Internacional de Estudos Poloneses, que se realizou na UFPR, em Curitiba, de 30/11 a 04/12/2019.
} 
anos de existência do Curso de Letras Polonês da Universidade Federal do Paraná. ${ }^{4}$ Como há de ficar claro mais adiante, dimensionar devidamente a presença do teatro polonês no Brasil ao longo desse período ${ }^{5}$ proporciona lições valiosas, de importância estratégica para o futuro do curso (sem falar nas possíveis contribuições futuras do curso para o panorama da criação cênica brasileira, ampliando e intensificando nele a presença do teatro polonês). A aludida ressalva, por seu turno, concerne aos dados que me propus a buscar - e àqueles que, a despeito de seu interesse e relevância, não foram investigados nesta oportunidade. Meu foco incidiu nas coordenadas da cena, nos espetáculos que estiveram em cartaz, na efetividade da práxis teatral, em suas diversas manifestações, para diversos públicos pelo país. Felizmente, não faltaram em outros âmbitos iniciativas de mérito relacionadas às artes cênicas da Polônia (investidas acadêmicas e editoriais, por exemplo). En passant, será o caso de trazê-las à baila nas presentes considerações. ${ }^{6}$ Por ora, no entanto, sigamos

\footnotetext{
${ }^{4}$ Até o momento se trata da única graduação brasileira (e latino-americana, salvo engano) a oferecer formação - em bacharelado e licenciatura - em Letras Polonês. Stricto sensu, portanto, trata-se da única Polonística do país. Mas o termo também tem emprego lato sensu no artigo; neste último caso, entenda-se polonística como o conjunto de todos os pesquisadores atuantes na área, em diversas universidades pelo Brasil, independentemente da exata lotação de cada um nos quadros de sua instituição.
}

${ }^{5}$ Sem que nos esqueçamos, outrossim, da longa história precedente - ainda por ser contada e analisada em pormenor - de contatos entre nosso teatro e o polonês. Vale registrar, aliás, que um importante capítulo da crônica desses contatos foi recentemente revisitado: ver PLUTA (2015a, 2015b). Sobre a "turma da Polônia" no contexto da modernização do teatro brasileiro, ver FUSER; GUINSBURG (1992).

${ }^{6}$ Para efeito de rápida ilustração, cabe anotar antes de mais nada o lançamento de alguns livros. Em 2008 (um ano antes, portanto, do intervalo de tempo aqui em foco), vem a lume em tradução brasileira $O$ teatro da morte, coletânea de escritos de Tadeusz Kantor organizada pelo estudioso francês Denis Bablet (ver KANTOR, 2008). Nos anos seguintes, é o legado criativo grotowskiano que recebe atenção de editores brasileiros; ver FLASZEN; POLLASTRELLI; MOLINARI (2010) e FLASZEN (2015). São dadas à estampa nos últimos anos, além disso, obras de fôlego de duas estudiosas brasileiras de Grotowski; ver LIMA (2012) e OLINTO (2017). Deixo aqui registrado um caloroso agradecimento ao Parecerista cujas observações trouxeram a meu conhecimento a publicação do livro de Lidia Olinto, bem como a de dois dossiês temáticos consagrados a Grotowski: um na Revista Brasileira de Estudos da Presença, em 2013 $<$ https://seer.ufrgs.br/presenca/issue/view/1769> e outro, recém-vindo a lume, na revista Moringa $<$ https://periodicos.ufpb.br/index.php/moringa/index $>$. Cabe ainda, por fim, recordar as empreitadas acadêmicas, destacando, entre elas, três importantes eventos dedicados ao criador do Teatr Laboratorium: em 2009, o Seminário Internacional Grotowski: Uma Vida Maior do que o Mito, na UNIRIO (com programação itinerante em outras universidades brasileiras); em 2015, o I Encontro Internacional Repensando Mitos Contemporâneos: Simpósio Grotowski, na UNICAMP; e, em 2019, o Seminário Internacional Grotowski: Uma Cultura Ativa, na UNIRIO (mais uma vez, com programação itinerante em outras universidades: UFMG, UFOP, UFSM e $\mathrm{UnB})$. 
o rastro do teatro polonês nos nossos palcos durante a década passada.

Desde logo, saltam aos olhos participações de convidados poloneses no extenso circuito de mostras e festivais de artes da cena promovidos em diferentes cidades brasileiras. Graças à notável multiplicação desses eventos desde os anos 1990 e aos esforços combinados de seus produtores, diretores e curadores, a distância que nos separa do mundo teatral da Polônia tem sido superada em repetidas ocasiões nos últimos dez anos. ${ }^{7}$ Em 2015, na $16^{\mathrm{a}}$ edição do Cena Contemporânea - Festival Internacional de Teatro de Brasília, Jolanta Juszkiewicz apresentou o espetáculo solo The mother, uma das obras do repertório do Kropka Theatre, o teatro nômade criado pela atriz e diretora em 1997, em Sydney, na Austrália. ${ }^{8}$ A despojada e bela encenação, ${ }^{9}$ codirigida por Anatoly Frusin e pela própria Juszkiewicz (também responsável pela adaptação do texto da montagem), trouxe de novo a uma plateia do Brasil a peça Matka (1924), de Stanisław Ignacy Witkiewicz (1885-1939), exibida pela primeira vez no país em 1971, em plena ditadura, no histórico espetáculo sob a direção de Claude Régy, no Rio de Janeiro, com Tereza Raquel no papel principal. ${ }^{10}$

Em 2016 e 2018, mais duas empreitadas, ambas de incomum envergadura - quer pelos custos de produção envolvidos, quer pelo cacife artístico em jogo em cada uma delas. Na terceira edição da Mostra Internacional de Teatro de São Paulo, em 2016, o público brasileiro pôde achar-se frente a frente com o formidável (A)pollonia, de Krzysztof Warlikowski. E dois anos depois, na $5^{\text {a }}$ MITsp, enfim pôde ser vista em um de nossos palcos uma encenação de Krystian Lupa: Wycinka/Holzfällen, sua virtuosística adaptação teatral do romance Árvores abatidas, do austríaco Thomas Bernhard. Com

\footnotetext{
${ }^{7}$ É doloroso verificarmos como esse passado tão próximo - já parece tão distante! Muito vulnerável aos altos e baixos da economia e à (crônica) falta de uma política esclarecida, democrática e consistente de apoio às artes cênicas no país, o que será de nosso circuito de mostras e festivais de teatro sob o governo eleito em 2018, que tem entre suas bandeiras não apenas vilipendiar, mas também erodir e solapar a cultura brasileira? Sobre as concepções de curadoria cênica de vários festivais de teatro no Brasil, ver ROLIM (2017).

${ }^{8}$ Sobre o Kropka Theatre, ver $<$ https://www.zasp.pl/index.php?page=Pages\&id=1336>. Sobre o Cena Contemporânea de 2015, ver <http://objetosim.com.br/cena-contemporanea-festivalinternacional-de-teatro-de-brasilia-5/>.

${ }^{9}$ Um registro em vídeo da versão em polonês do espetáculo está disponível em $<$ https://vimeo. com/296241503>. No Cena Contemporânea, Juszkiewicz atuou em inglês.

${ }^{10}$ Sobre $A$ mãe encenada por Régy no Rio, ver o verbete dedicado à montagem na Enciclopédia Itaú Cultural $-<$ http://enciclopedia.itaucultural.org.br/evento399208/a-mae $>-$ e os primorosos textos críticos de MICHALSKI (2004).
} 
uma pujante trajetória criativa que remonta aos tempos da cortina de ferro e da República Popular da Polônia, ${ }^{11}$ aclamado por crítica e público nos quatro cantos do mundo, Lupa foi saudado na MITsp como "um dos grandes mestres das artes cênicas contemporâneas"12 e mereceu dos organizadores do evento uma programação especial, que incluiu, além de uma entrevista pública, um workshop com o diretor. Mas também Warlikowski (que foi aluno de Lupa e seu assistente de direção, convém recordar) teve sua estatura justamente apreciada pela MITsp, que o recebeu como um "dos mais proeminentes diretores europeus de sua geração", empenhado - sem temer polêmicas ou escândalos - em "experiências cênicas de ponta na investigação de questões estéticas, éticas e políticas". ${ }^{13}$

Convém assinalar que a vinda dos espetáculos de Lupa e Warlikowski ao Brasil só foi viabilizada mediante o apoio do Instituto Adam Mickiewicz. Em 2016, aliás, o IAM levou a cabo um alentado projeto de promoção da cultura polonesa entre nós, ao qual devemos outra feliz empreitada em nosso meio teatral. De 17 a 23 de outubro, a programação da $7^{\mathrm{a}}$ edição do TEMPO_FESTIVAL - Festival de Artes Cênicas do Rio de Janeiro trouxe entre seus destaques um expressivo recorte da cena contemporânea da Polônia. Ao longo do evento, juntamente com uma série de outras atividades dedicadas ao teatro polonês, foram apresentados quatro espetáculos: o solo Mała narracja (Pequena narrativa), texto, concepção cênica e atuação de Wojtek Ziemilski; Samotność pól bawetnianych, montagem de Na solidão dos campos de algodão, de Bernard-Marie Koltès, dirigida por Radosław Rychcik; Ewelina płacze (Ewelina chora), encenação e texto de Anna Karasińska, com a colaboração de Magdalena Rydzewska na dramaturgia; Apokalipsa (Apocalipse), com

${ }^{11}$ Lupa estreia na direção em 1976, com uma montagem da peça Rzeźnia (O matadouro), de Sławomir Mrożek, na cena Miniatura do teatro Juliusz Słowacki, em Cracóvia. Sobre a trajetória do encenador até a montagem de Rodzeństwo (Ritter, Dene, Voss), de Thomas Bernhard, em 1996, ver NIZIOŁEK (1997). Olga Śmiechowicz (2018) analisa as realizações de Lupa desde os anos 1990 até Persona. Tryptyk/Marylin, que entra em cartaz em 2009. Ver ainda GRUSZCZYŃSKI (2003).

12 Conf. o texto da "Apresentação" do catálogo cartografias.MITsp_5 2018. Disponível em: $<$ https://mitsp.org/2018/publicacoes/> No mesmo endereço eletrônico, ver no Guia dessa edição da Mostra a ficha técnica de Árvores abatidas.

${ }^{13}$ As formulações citadas provêm, respectivamente, do Guia Oficial da Mostra de 2016 e da "Apresentação" do catálogo cartografias MITsp_03 2016. Todo esse material está disponível em <https://mitsp.org/2016/publicacoes/>. No Guia, ver a ficha técnica de (A)polônia. Sobre Warlikowski, ver ŚMIECHOWICZ (2018) e GRUSZCZYŃSKI (2003). Neste último, são discutidas realizações do encenador que datam de 1997 (Elektra, de Sófocles) até 2001 (Oczyszczeni [Cleansed], de Sarah Kane). Śmiechowicz analisa a carreira de Warlikowski desde sua - malograda - estreia em 1993 (com uma adaptação de Kleist, Markiza O.) até o espetáculo Opowieści afrykańskie wedtug Szekspira (Relatos africanos segundo Shakespeare), de 2011. 
direção de Michał Borczuch e dramaturgia de Tomasz Śpiewak. ${ }^{14}$

O que se expôs até aqui talvez não deixe de surpreender. Não que, em termos absolutos, o somatório dos espetáculos mencionados seja de monta. Cá para nós, no entanto, o quadro com certeza não é mau. Sete espetáculos - entre eles um Bernhard de Lupa, $(A)$ pollonia, de Warlikowski, e Mała narracja, de Ziemilski -, em três capitais brasileiras, em um intervalo de uma década! A concentração da quase totalidade dessas apresentações no assim chamado "eixo Rio-São Paulo" não pode passar despercebida, como tampouco a incidência de sua esmagadora maioria em um só ano, graças a providenciais recursos financeiros provenientes da Polônia. Retomaremos esses pontos, tão logo se passem em revista os resultados das incursões criativas de artistas da cena do Brasil pelos territórios do teatro polonês.

A primeira realização cênica a registrar tomou como ponto de partida a única obra da literatura dramática polonesa até hoje traduzida e publicada em livro em nosso país, Przed sklepem jubilera (Diante da loja do ourives), de Karol Wojtyła. ${ }^{15}$ Assim como toda a produção dramatúrgica de seu autor, a peça revela uma estreita afinidade formal com a linguagem do Teatro Rapsódico de Mieczysław Kotlarczyk, cujas apresentações clandestinas em Cracóvia, sob a ocupação nazista, tiveram a participação do jovem Wojtyła como ator. Exibindo-se em residências privadas, para plateias com um punhado de pessoas, o Teatro Rapsódico foi um teatro de câmara, de encenações materialmente ascéticas, centradas na austera recitação do texto, na depurada força de expressão da palavra e da poesia. ${ }^{16}$ Nessa "fonte teatral", aponta um estudioso, a dramaturgia wojtyliana hauriu seu apreço pelo "alto-relevo da palavra", bem como seu peculiar "intelectualismo" (CIECHOWICZ apud JABŁOŃSKA, 2014, p. 158), sua ênfase no plano das ideias e do pensamento, não no desenho das personagens ou na urdidura da ação. Wojtyła "se afasta de nossos hábitos e gostos teatrais", afirma outro conhecedor de sua obra, salientando

\footnotetext{
${ }^{14}$ Ver na página do festival - <https://tempofestival.com.br/anos/2016/> - a programação de 2016 (no link de cada espetáculo está disponível a respectiva ficha técnica). No site também pode ser encontrado o release dessa edição do evento, bem como algum material em torno das apresentações polonesas (fotos, entrevistas com Wojtek Ziemilski e Michał Borczuch etc.). Como no caso de (A) pollonia na MITsp 2016, a Prefeitura de Varsóvia cofinanciou a vinda dos artistas da Polônia para o TEMPO FESTIVAL.

${ }^{15}$ A edição brasileira (WOJTYLA, 1980), A loja do ourives (sem subtítulo), teve por base a tradução italiana da peça (JAWIEŃ, 1979). O original - Przed sklepem jubilera. Medytacja o sakramencie matżeństwa przechodzaca chwilami $w$ dramat - veio a lume pela primeira vez na revista Znak, em 1960, sob o pseudônimo Andrzej Jawień.
}

${ }^{16}$ Sobre o Teatro Rapsódico, ver POPIEL (2006). 
o aspecto "não convencional e - o que talvez espante mais - experimental" das peças do autor: em "tempos de um teatro aberto a quaisquer impressões, sensações e excessos superficiais, epidérmicos", o drama wojtyliano "vai ao âmago do homem (...) e se desenrola em seu íntimo, empregando para tanto meios formais complicados, mas extremamente interessantes" (TABORSKI apud JABŁOŃSKA, 2014, p. 162-163).

Diante dessa sumária caracterização, já dispomos do bastante para verificar com nitidez o perfil do Wojtyła brasileiro que entrou em cartaz no TUCA, em São Paulo, em 2012, sob o título Enlace - a loja do ourives. ${ }^{17} \mathrm{E}$ a metamorfose do autor na montagem foi substancial! Pois o espetáculo que então se deu a ver, em tudo avesso a minimalismos cênicos e a quaisquer experimentações formais apartadas dos hábitos e gostos do público, era um bem cuidado musical ${ }^{18}$, exemplarmente cioso das convenções do gênero tal como encontradiço na Broadway: produção irretocável, bela cenografia, ricos figurinos, grande elenco. Dramaturgia com um tanto de humor e outro tanto de sentimental, culminando em indefectível happy end e, como principal estrela do espetáculo, a música, o apuro técnico e o poder expressivo do canto das atrizes e atores, acompanhados por uma ótima banda. A direção geral coube a Jô Santana; a adaptação do texto, a Elísio Lopes Jr.; a direção cênica, por sua vez, ficou a cargo de Roberto Lage; das composições e da direção musical se incumbiu Thiago Gimenes. À temporada no TUCA - que se estendeu de 19 de maio a 12 de agosto de 2012 - sucederam-se, já em 2013 (com mudanças no numeroso elenco), apresentações em tournées em Recife e Fortaleza, e uma temporada de 4 a 28 de julho no teatro Imperator - Centro Cultural João Nogueira, no Rio de Janeiro. ${ }^{19}$ Evitando instilar no termo uma conotação apressadamente pejorativa, cabe sem dúvida no caso o rótulo de teatrão, o que tem um quê de irônico e dá muito o que pensar: o que se realizou no palco, afinal, em Enlace - a loja do ourives, foi um desembaraçado, atento diálogo artístico com a dramaturgia wojtyliana? Ou o decisivo aqui, de fato, foi o vulto venerando do papa João Paulo II, a emprestar sua aura a uma empreitada teatral de evidente vocação para o entretenimento?

No caso de ambas as montagens comentadas a seguir, decerto pesou decisivamente o recado que cada texto tinha a dar, a potência de cada um como artefato de linguagem,

\footnotetext{
${ }^{17}$ Ver, na página do TUCA, o material disponível sobre o espetáculo: $<$ http://www.teatrotuca.com. br/espetaculos/espetaculo_enlace_historia_de_ourives.html $>$.

${ }^{18}$ Sobre as noções de teatro musical e teatro musicado, ver os dois verbetes correspondentes, de autoria de Neyde Veneziano, em GUINSBURG; FARIA; LIMA (2006, p. 190-191).

19 Ver <https://abroadwayeaqui.com.br/2013/07/08/enlace-a-loja-do-ourives-chega-ao-rio-dejaneiro/>
} 
não a aura em torno de sua autoria. 19 de julho de 2013, no palco do Núcleo Experimental, em São Paulo, estreia a primeira montagem brasileira de uma obra do dramaturgo polonês contemporâneo Tadeusz Słobodzianek: Nossa classe, adaptada e dirigida por Zé Henrique de Paula. Graças à expressiva recepção inglesa de Nasza klasa - sob a direção de Bijan Sheibani, Our class estreou em Londres, no National Theatre, 16 de setembro de $2009^{20}$ -, o encenador brasileiro teve sua atenção despertada pela peça. E não por acaso. Em um elogiado espetáculo anterior do Núcleo Experimental, As troianas - vozes da guerra (que entra em cartaz, por coincidência, em junho de 2009), Zé Henrique levou a cabo uma adaptação livre da tragédia de Eurípides, deslocando-a drasticamente, no espaço e no tempo, para trás do arame farpado de um campo de concentração nazista. Ali, transformadas em prisioneiras judias, Hécuba, Cassandra, Andrômaca e Helena confrontavam seus algozes, não mais antigos aqueus, mas sim soldados e oficiais sob as insígnias do Terceiro Reich. ${ }^{21}$

No drama de Słobodzianek (2009), com seu lastro histórico nos cruentos episódios do pogrom de Jedwabne, a memória traumática da Shoah é revisitada com dureza e Zé Henrique de Paula e os demais responsáveis pela encenação brasileira de Nasza klasa, corajosamente, possibilitaram que os questionamentos propostos pela obra também ressoassem entre nós. ${ }^{22}$ Em hora muito conturbada e oportuna, convém lembrar, conforme se atesta em uma valiosa crítica da montagem publicada 3 de agosto de 2013 no blog Jogo de Cena. A autora salienta o impacto produzido pelo espetáculo “- e não só pelo evento que retrata, o massacre de Jedwabne"; acima de tudo, a peça de Słobodzianek

\footnotetext{
${ }^{20}$ Tratou-se, com efeito, da estreia mundial da peça, já que a primeira montagem na Polônia - sob a direção de Ondrej Spišák - só subirá ao palco do Teatr na Woli, em Varsóvia, 16 de outubro de 2010. O espetáculo no National Theatre utilizou a versão inglesa de Nasza klasa elaborada por Ryan Craig, a partir da "tradução literal" do texto polonês de Catherine Grosvenor. Our class é publicada em livro já em 2009 e desde então teve várias reimpressões (ver SŁOBODZIANEK, 2013). O texto da montagem brasileira - traduzido por Zé Henrique de Paula - teve por base essa versão inglesa.

${ }^{21}$ Reimaginando o destino trágico das mulheres de Troia no cenário da Shoah, Zé Henrique concebeu uma solução cênica especialmente engenhosa: ao longo de todo o espetáculo, as falas em alemão! - constituem uma prerrogativa dos nazistas/aqueus; suas vítimas, ao contrário, como se destituídas da própria possibilidade da fala, só se expressam por meio do corpo e do canto (a trilha sonora da montagem é de Fernanda Maia). Sobre As troianas - vozes da guerra, ver $<$ http:// nucleoexperimental.com.br/portfolio-item/troianas/\#1465855296812-2128705b-6297d1df-d091>.

${ }^{22}$ Ver o material disponível sobre Nossa classe (ficha técnica do espetáculo, fotos, release etc.) na página do Núcleo Experimental: <http://nucleoexperimental.com.br/portfolio-item/nossaclasse/\#1465855303899-b970319a-aeb20568-c7b4>. À luz da recepção crítica das montagens inglesa e brasileira da obra de Słobodzianek, Ribeiro (2019) discute o intrincado problema do referencial histórico de Nasza klasa.
} 
faz um flagrante preciso do nascimento das intolerâncias, do recrudescimento de posições, da gradativa cegueira provocada pelo ódio (...). Confesso que fiquei um tanto abalada; assisti ao espetáculo logo na estreia, algumas semanas depois das grandes manifestações de rua no Brasil, quando circulavam opiniões exaltadas e polarizadas sobre os últimos eventos do cenário sociopolítico do país (VOMERO, 2013).

Nossa classe permaneceu em cartaz, em sua primeira temporada, até 15 de setembro de 2013. Pouco mais de dois anos depois, voltou ao palco, graças a uma campanha de financiamento coletivo organizada pelo próprio elenco (bravíssimo!), para uma segunda temporada, que se prolongou de 04 de março a $1^{\text {o }}$ de maio de 2016. Que venham outras, para que o impacto salutar de uma realização tão louvável alcance mais plateias pelo Brasil!

Ao que tudo indica, o contexto sociopolítico do país de novo assume um papel de relevo na próxima iniciativa sob escrutínio. Comemorando os 40 anos de sua fundação, o Grupo Proteu, de Londrina, leva ao palco de 03 a 05 de maio de 2019 um clássico do teatro polonês moderno, Tango, de Sławomir Mrożek. ${ }^{23}$ Um golpe doméstico perpetrado por motivações reacionárias, que abre caminho, inopinadamente, para o truculento triunfo autocrático de um patife: qualquer semelhança entre as reviravoltas da ação da peça (de 1964!) e vicissitudes dos últimos tempos no Brasil - será apenas coincidência? Inebriado ante a perspectiva de afinal tomar em suas mãos as rédeas do poder familiar, Artur vocifera:

\begin{abstract}
Olhem pra mim, eu sou a coroa dos seus sonhos! Tio, vai haver ordem! Pai, você sempre se revoltou, mas a sua revolta levou somente ao caos, até que ele devorou a si mesmo! E olhe pra mim! O poder também não é uma revolta? Uma revolta em forma de ordem, uma revolta do topo contra o que há embaixo, da superioridade contra a inferioridade? O cume precisa da planície, a planície precisa do cume, para que não deixem de ser o que são. E assim desaparece no poder toda contradição entre os opostos. Não sou nem síntese, nem análise, eu sou o ato, sou vontade, sou energia. Força, é isso que eu sou! (MROŻEK, 2000, p. $\left.183-184^{24}\right)$
\end{abstract}

\footnotetext{
23 Ver o material de divulgação do espetáculo na página do Teatro Ouro Verde: $<$ https://teatroouroverde.wordpress.com/2019/04/29/tango-de-mrozek-grupo-proteu-40-anos/>. A montagem também fez duas apresentações na edição de 2019 do Festival Internacional de Londrina. Ver <https://filo.art.br/proteu-no-filo-50-1/>
}

${ }^{24}$ Cito em minha tradução do texto polonês da peça. 
Instaurada a lei do mais forte, no entanto, sua primeira vítima é ninguém menos que o próprio Artur, que titubeia em seus intentos e acaba assassinado, de modo traiçoeiro e brutal, por outro morador da casa, Edek, descrito na didascália inicial da peça como um sujeito "obscuro e suspeito no mais alto grau" (MROŻEK, 2000, p. 78). Seguindo-se à chocante performance de seus punhos, o pouco que Edek se digna a dizer às demais personagens ganha a eloquência de um péssimo augúrio: "Agora é minha vez. E vocês vão me escutar" (MROŻEK, 2000, p. 192).

A encenação londrinense do texto mrożkiano foi dirigida por William Pereira, que declarou durante a etapa final de ensaios que sua admiração por Tango vem desde os anos 1980, quando conheceu a obra. ${ }^{25} \mathrm{Na}$ opinião do diretor, trata-se de "um dos grandes textos de teatro do século XX", de uma "atualidade (...) imensa". E acrescenta, reveladoramente: "É um texto que tenho certeza que a Nitis Jacon adoraria. Um texto que se adapta à estética - e à ética - do Proteu." (N.COMLONDRINA, 2019). A história do grupo, criado em 1978, concede inteira razão a tais palavras. Fundadora e primeira diretora do Projeto de Teatro Experimental Universitário, Nitis Jacon conseguiu a façanha de pôr em cena em 1979, apesar das interferências da censura, o musical Calabar, de Chico Buarque e Ruy Guerra. ${ }^{26} \mathrm{E}$ a própria recepção do teatro de Mrożek entre nós também corrobora as afirmações de William Pereira: a estreia carioca da primeira montagem brasileira de uma peça do dramaturgo - Tango, precisamente, sob a direção de Amir Haddad, em 1972 inscreveu-se de forma luminosa na crônica dos anos de chumbo, como um ímpeto de resistência do nosso teatro perante as armas do autoritarismo. Honrando essa intrépida tradição estética, ética e política, o Proteu não deixou por menos. Diante de redivivas sanhas obscurantistas e autoritárias, ei-lo de novo no palco, em festa e em combate, com uma nova montagem do velho e bom Tango mrożkiano. Vivas e bravos!

O cômputo até esta altura, somadas as visitas de artistas da Polônia e criações de gente da cena do Brasil, completa um número redondo: dez espetáculos (um deles no Centro-Oeste, outro com rápidas incursões pelo Nordeste, outro, enfim, realizado no Sul do país). Basta - para não alongar em demasia o presente artigo -, mas não deixemos que passem sem um breve aceno de reconhecimento algumas outras empreitadas, todas

${ }^{25}$ Os comentários do diretor constam do texto "Grupo Proteu comemora 40 anos com montagem de Tango" (N.COMLONDRINA, 2019, sem paginação).

${ }^{26}$ Recordemos que a primeira tentativa de montagem de Calabar, em 1973, com produção de Fernando Torres e Fernanda Montenegro, foi torpemente interditada, pouco antes da estreia, em uma das (tantas!) ofensivas da censura em pleno AI-5. Sobre o assunto, ver MICHALSKI (1979, p. 51-52, 81-83). Sobre o Calabar do Proteu, exibido na $12^{\mathrm{a}}$ ed. do FILO, em 1979, ver JACON (2010, p. 106-108). 
muito significativas (duas delas fora do eixo Rio-São Paulo): Desterrados - UR EX DES MACHINE, da Companhia Antropofágica, de São Paulo, em 2015, Sanatorium, d'A Turma do Dionísio, de Santo Ângelo das Missões, no Rio Grande do Sul, em 2018, e, em 2019, Erradicação, de Maciej Rożalski, que, além de ator e dançarino, é professor e pesquisador da área de Artes do Espetáculo na Universidade Federal do Recôncavo da Bahia.

Com direção de Thiago Reis Vasconcelos e dramaturgia coletiva da Cia. Antropofágica, Desterrados teve seu pontapé inicial em 2010, em um ciclo de estudos teóricos e práticos sobre o teatro de Kantor desenvolvidos pela companhia com a participação de Michał Kobiałka e Ludmiła Ryba (os dois foram consultores cênicos do espetáculo). A encenação estreou na programação paralela da exposição Máquina Tadeusz Kantor, realizada no SESC Consolação, em São Paulo, de 19/08 a 14/11 de 2015. ${ }^{27}$ Sanatorium levou ao palco, com direção, adaptação e atuação de Jerson Fontana, contos de Bruno Schulz (além de diversas apresentações pelo país, a montagem foi exibida em Drohobycz, na Ucrânia, no Festival Bruno Schulz, bem como em Lublin e Gdańsk, na Polônia). ${ }^{28}$ Erradicação, enfim, originou-se do trabalho de Maciej Rożalski em torno da ideia de multidramaturgias, de processos de criação de linguagens cênicas de caráter interdisciplinar. O espetáculo fez sua estreia no âmbito do evento Dramaturgias em Trânsito, Arte Pesquisa, Pesquisa Arte, realizado em Santo Amaro, na Bahia. ${ }^{29}$

\section{TRADUZIR (PARA O) TEATRO}

Não nos detivemos no assunto até agora, mas espero que estejamos de acordo - em cada iniciativa artística anteriormente referida, a parte que toca à tradução é nada menos que fundamental. E isso se aplica, cumpre ressaltar, a toda a extensa gama de

\footnotetext{
${ }^{27} \mathrm{Na}$ página da Cia. Antropofágica, ver a ficha técnica do espetáculo: $<\mathrm{https}: / / \mathrm{www}$.antropofagica. com/desterrados-ur-ex-des-machine>. Ver também o "Histórico" da companhia. Kobiałka, como se sabe, é um renomado estudioso do criador d'A classe morta; e Ludmiła Ryba foi atriz do Cricot 2 .

28 Ver, na página d'A Turma do Dionísio, o material disponível sobre Sanatorium: $<$ www.aturmadodionisio.com.br/home.php $>$.

${ }^{29}$ Ver a apresentação e a programação do evento na página $<$ https://www2.ufrb.edu.br/bicult/ eventos/68-dramaturgias-em-transito-arte-pesquisa-pesquisa-arte-2>. Rożalski fez uma apresentação do espetáculo (sob novo título: Erradicações) em Curitiba, na programação do I Encontro Internacional de Estudos Poloneses. E a Turma do Dionísio também se apresentou no Encontro com seu Sanatorium.
} 
variantes da prática tradutória que se fazem perceptíveis no conjunto de encenações consideradas: a tradução para a legendagem de espetáculos estrangeiros, para a realização de uma montagem teatral determinada ou para a publicação em livro; a tradução direta ou indireta; a tradução de obra de literatura dramática ou de qualquer outra espécie de texto dramatúrgico (adaptações de textos de outros gêneros, colagens textuais, roteiros dramatúrgicos resultantes de processos de improvisação e de escrita em cena etc.). Sem falar, além disso, no fascinante processo de tradução das apresentações em língua de sinais, para bem da acessibilidade no teatro.

Essa imponente diversidade do fazer tradutório relacionado com a cena exige máxima atenção. A labilidade semântica do sintagma "traduzir (para o) teatro" intenta alertar para o problema, movendo um leque de acepções que compreende desde o traslado de literatura dramática (um dos sinônimos de "teatro" em português) até os vários tipos de tradução cujo escopo se volta para o palco. Até pouco tempo atrás, todavia, amiúde a questão andou ignota ou negligenciada. ${ }^{30}$ Hoje, mais e mais, felizmente vem à tona com vigor, ${ }^{31}$ e junto com ela implicações maiúsculas, em diferentes campos. Para o exercício do traduzir, desde logo, ante o qual se franqueiam demandas particularizadas e promissores espaços de atuação profissional em todos os quadrantes do mundo teatral; para os estudos da tradução, obviamente, sob cuja alçada se encontram as tarefas de descrição, teorização e crítica das numerosas modalidades de traslado vinculadas ao teatro, bem como o dever de pensar a formação e o aprimoramento de competências tradutórias adequadas nesse amplo domínio; e para os estudos teatrais, enfim, na medida em que diversas formas de tradução integram as dinâmicas de criação e de recepção das artes cênicas, solicitando, portanto, a devida perquirição de seus especialistas.

Teoricamente falando, em todas as frentes de ação que aí se abrem, com seus muitos desafios, a polonística pode oferecer contribuição substantiva. E a evidência

\footnotetext{
${ }^{30}$ Sintomaticamente, uma obra de referência internacional prestigiada como a Routledge Encyclopedia of Translation Studies, até sua segunda edição - lançada em capa dura em 2009 - só continha o verbete "Drama translation", traindo assim o obsoleto pressuposto textocêntrico de que a arte do teatro se reduz apenas a pôr em cena a literatura dramática (BAKER; SALDANHA, 2011). Na terceira edição da Encyclopedia, dada à estampa em 2019, o verbete "Drama translation" foi substituído; figura agora no índice o verbete "Theatre translation". Ver o anúncio do (caríssimo!) livro na página da editora: $<$ https://www.routledge.com/Routledge-Encyclopedia-of-Translation-Studies-3rd-Edition/ Baker-Saldanha/p/book/9781138933330>.
}

${ }^{31}$ Para uma discussão lúcida e muito bem informada acerca do problema, ver BOHUNOVSKY (2019). 
empírica submetida a exame nestas páginas parece sugerir o mesmo. Os dados atinentes à tradução, antes de mais nada, desvelam um quadro inequívoco. Entre os espetáculos de artistas brasileiros, só em um caso - Sanatorium, d'A Turma do Dionísio - a montagem teve à sua disposição um texto vertido diretamente do polonês (Jerson Fontana adaptou contos schulzianos $^{32}$ traduzidos para a língua portuguesa por Henryk Siewierski e vindos a lume em livro em meados dos anos 1990). ${ }^{33}$ Em Enlace - a loja do ourives, a adaptação pôde ao menos se servir de uma edição brasileira da peça de Karol Wojtyła, traduzida, porém, da versão italiana da obra, conforme verificamos. O Słobodzianek do Núcleo Experimental, como também já se observou, teve por base a tradução inglesa de Nasza klasa; o Mrożek do Proteu, por sua vez, traduzido e adaptado pelo diretor William Pereira, valeu-se das versões de Tango em língua francesa e inglesa. E no que se refere aos espetáculos poloneses exibidos na MITsp e no TEMPO_FESTIVAL, a situação não melhora: juntamente com Luiz Henrique Budant, ${ }^{34}$ traduzi do polonês o texto das legendas para a apresentação da montagem de Krystian Lupa. A legendagem de todos os demais espetáculos que passamos há pouco em revista, porém, recorreu a uma versão intermediária em língua inglesa. ${ }^{35}$

Sob lentes inclinadas à melancolia, a paisagem toma cor algo cinzenta e desalentadora! Traduções de dramaturgia polonesa publicadas, ao que se vê, inexistem; pior ainda, assim como nossos editores, nem encenadores nem produtores teatrais brasileiros aparentam especial diligência para contarem com textos traduzidos diretamente do respectivo original polonês... Tentemos, contudo, um outro olhar: ali onde se detectam senões e lacunas, precisamente, não estão à nossa espera projetos instigantes, objetivos prioritários, esforços de que não devemos prescindir? Iniciativas tradutórias, antes de mais nada, avultam no atual estado de coisas como um imperativo categórico. Tenham elas como propósito imediato o livro ou a ribalta. (Como propósito imediato, frisemos, porque não raro o que se traduz para uso cênico vem a ser publicado e vice-versa: o

\footnotetext{
32 Três contos, exatamente: "Solidão", "O aposentado" e "Sanatório sob a clepsidra", texto do qual provém o título da encenação. Ver SCHULZ (1994).

${ }^{33}$ Erradicação configura um caso à parte: o espetáculo lança mão apenas de uns poucos fragmentos textuais (trechos escolhidos de Kwiaty polskie, de Julian Tuwim, e Dziennik, de Witold Gombrowicz), a maior parte deles em polonês e o restante em tradução própria de Maciej Rożalski.

${ }^{34}$ Intérprete e tradutor profissional, egresso do curso de Letras Polonês da UFPR.

${ }^{35}$ Segundo o que foi possível apurar. Deploravelmente, é prática rotineira nesses eventos omitir no material de divulgação e nas fichas técnicas os devidos créditos do trabalho tradutório.
} 
dramaturgo traduzido para uma empreitada editorial, cedo ou tarde, vem a alimentar os expedientes da invenção teatral. ${ }^{36}$ )

Ficou demonstrado, no entanto, que o teatro polonês já vem frequentando com razoável regularidade - e não pouco destaque - os palcos do Brasil. O que de modo algum pode ser dito, aliás, admitamos sem rodeios, no que respeita ao mundo de nossas letras... Ora, sendo assim, que a jovem Polonística brasileira não se faça rogar, prestando de bom grado toda a contribuição a seu alcance na esteira da vida teatral do país. Porque não se trata só (?!) de traduzir. Trata-se, igualmente, de adensar a recepção crítica de obras polonesas postas em cena entre nós, interrogando-as, com rigor, em perspectivas abrangentes, sob distintas constelações disciplinares. Nesse sentido, é fácil concluir, duas alianças operacionais se afiguram indispensáveis. Com os estudos da tradução, por um lado, pois as versões dos textos utilizados nas montagens, elaboradas por via direta ou indireta, merecem análise meticulosa, discussão refletida e construtiva. E com os estudos teatrais, por outro: para amplificar ao máximo o poder de reverberação do palco nacional em seu diálogo - traduzido - com a Polônia e com todas as urgências que o cercam. Para que as redes de linguagem e de afeto lançadas por cada realização cênica se entrelacem em novos contextos, em novas tramas (inter)textuais e (inter)culturais, a partir do aqui e agora do espetáculo - e para além dele.

Ao terceiro sinal, então, já sabemos: mãos à obra. A cortina vai se erguer.

\footnotetext{
${ }^{36}$ Talvez não seja ocioso lembrar, com Jean-Pierre Sarrazac (2012, p. 67): a lógica moderna e contemporânea desses expedientes, atrelada às prerrogativas do encenador e a "uma emancipação mais ou menos radical do teatro com relação à jurisdição do literário", é a de uma "mise en jeu (...) concorrencial e polifônica do texto" e demais componentes do espetáculo.
} 


\section{REFERÊNCIAS:}

BAKER, Mona; SALDANHA, Gabriela (Ed.). Routledge Encyclopedia of Translation Studies; paperback edition. London and New York: Routledge, 2011.

BOHUNOVSKY, Ruth. Traduções no teatro, feitas para publicar, encenar ou legendar: uma tipologia possível. Urdimento, Florianópolis, v. 2, n $\mathrm{n}^{\mathrm{0}} 35$, p. 129-148, ago/set 2019. Disponível em: <http://www.revistas.udesc.br/index.php/urdimento/article/ view/1414573102352019129>. Acesso em 13 de jul. 2020.

FUSER, Fausto; GUINSBURG, Jacó. A "Turma da Polônia" na renovação teatral brasileira: presenças e ausências. In: SILVA, Armando Sérgio da (Org.). J. Guinsburg: diálogos sobre teatro. São Paulo: Edusp, 1992. p. 57-92.

FLASZEN, Ludwik; POLLASTRELLI, Carla; MOLINARI, Renata (Org.). O Teatro Laboratório de Jerzy Grotowski 1959-1969: textos e materiais de Jerzy Grotowski e Ludwik Flaszen com um escrito de Eugenio Barba. Trad. Berenice Raulino. São Paulo: Perspectiva/Edições SESCSP; Pontedera: Fondazione Pontedera Teatro, 2010.

FLASZEN, Ludwik. Grotowski \& companhia: origens e legado. Trad. Isa Etel Kopelman. São Paulo: É Realizações, 2015.

GRUSZCZYŃSKI, Piotr. Ojcobójcy: młodsi zdolniejsi $w$ teatrze polskim. Warszawa: W.A.B., 2003.

GUINSBURG, Jacó; FARIA, João Roberto; LIMA, Mariangela Alves de (Org.). Dicionário do teatro brasileiro: temas, formas e conceitos. São Paulo: Perspectiva; SESC SP, 2006.

JABŁOŃSKA, Monika. Penso o que meu coração sente: obra literária e pontificado de João Paulo II. Trad. Eduardo Nadalin e Marcelo Paiva de Souza. São Paulo: Globo, 2014.

JACON, Nitis. Memória e recordação: Festival Internacional de Londrina - 40 anos. Londrina: AMEN, 2010.

JAWIEŃ, Andrzej (Karol Wojtyła). La bottega dell'orefice: meditazioni sul sacramento del matrimonio che di tanto in tanto si transformano in drama. Trad. Aleksandra Kurczab e Jerzy Pomianowski con la collaborazione di Siro Angeli. Città del Vaticano: Libreria Editrice Vaticana, 1979.

KANTOR, Tadeusz. O teatro da morte. Textos org. e apresentados por Denis Bablet; trad. Jacó Guinsburg et al. São Paulo: Perspectiva/Edições SESC SP, 2008. 
LIMA, Tatiana Motta. Palavras praticadas: o percurso artístico de Jerzy Grotowski. São Paulo: Perspectiva, 2012.

MICHALSKI, Yan. O palco amordaçado: 15 anos de censura teatral no Brasil. Rio de Janeiro: Avenir, 1979.

MICHALSKI, Yan. O mundo despedaçado de $A$ mãe (I) e (II). In: MICHALSKI, Yan. Reflexões sobre o teatro brasileiro no século XX. Org. Fernando Peixoto. Rio de Janeiro: Funarte, 2004. p. 170-174.

MROŻEK, Sławomir. Tango. In: MROŻEK, Sławomir. Wybór dramatów; t. 1. Warszawa: Noir sur Blanc, 2000. p. 73-194.

NIZIOŁEK, Grzegorz. Sobowtór i utopia: teatr Krystiana Lupy. Kraków: Universitas, 1997.

N.COMLONDRINA. Grupo Proteu comemora 40 anos com montagem de Tango. Blog. Londrina. 3 abr. 2019. Disponível em: <https://blog.londrina.pr.gov.br/?p=51089>. Acesso em 13 de jul. 2020.

OLINTO, Lidia. Grotowski, grotowskianos e o paradoxo precisão-espontaneidade. Jundiaí: Paco Editorial, 2017.

PLUTA, Aleksandra. Ten piekielny polski akcent: Ziembiński na brazylijskiej scenie. Warszawa: Muzeum Historii Polskiego Ruchu Ludowego/Instytut Studiów Iberyjskich i Iberoamerykańskich UW, 2015a.

PLUTA, Aleksandra. Aquele bárbaro sotaque polonês: Ziembiński nos palcos brasileiros; trad. Luiz Henrique Budant. Varsóvia: Muzeum Historii Polskiego Ruchu Ludowego/ Instytut Studiów Iberyjskich i Iberoamerykańskich UW, 2015b

POPIEL, Jacek. Los artysty w czasach zniewolenia: Teatr Rapsodyczny 1941-1967. Kraków: Wydawnictwo Uniwersytetu Jagiellońskiego, 2006.

RIBEIRO, Jorge Rafael Krebs. Nossa classe, de Tadeusz Słobodzianek: teatro, verdade histórica e recepção crítica. In: CONGRESSO INTERNACIONAL ABRALIC, 16., 2019, Brasília. Anais Eletrônicos do XVI Congresso Internacional Abralic 2019: circulação, tramas \& sentidos na literatura. Brasília: Abralic, 2019, p. 3661-3672 (v. II). Disponível em: <http://www.abralic.org.br/anais/>. Acesso em 13 de jul. 2020.

ROLIM, Michele. O que pensam os curadores de artes cênicas. Rio de Janeiro: Cobogó, 2017. 
SARRAZAC, Jean-Pierre (Org.). Léxico do drama moderno e contemporâneo. Trad. André Telles. São Paulo: Cosac Naify, 2012.

SCHULZ, Bruno. Sanatório. Trad. Henryk Siewierski. Rio de Janeiro: Imago, 1994.

SŁOBODZIANEK, Tadeusz. Nasza klasa: historia w XIV lekcjach. Gdańsk: słowo/obraz terytoria, 2009.

SŁOBODZIANEK, Tadeusz. Our class; in a version by Ryan Craig, from a literal translation by Catherine Grosvenor. London: Oberon Books, 2013.

ŚMIECHOWICZ, Olga. Polski teatr po upadku komunizmu: Lupa, Warlikowski, Klata. Warszawa: PWN, 2018.

VOMERO, Maria Fernanda. O lado sombrio da humanidade. Blog Jogo de Cena, 03 ago. 2013. Disponível em: <http://blogjogodecena.com.br/tag/ze-henrique-de-paula/>. Acesso em 13 de jul. 2020.

WOJTYLA, Karol. A loja do ourives. Trad. Leopoldo Scherner, com a colaboração de Luís Artigas Mayayo. São Paulo: Loyola, 1980. 